\title{
Tożsamość w skali mikro - \\ człowiek i jego przestrzeń
}

Micro scale identity - human and his space

\section{Streszczenie}

Artykuł porusza temat tendencji w kształtowaniu przez człowieka otaczającej go przestrzeni i ich powiązań z tożsamością i tradycją domu rodzinnego. Omówienie znaczenia domu rodzinnego w kształtowaniu tożsamości nowego miejsca zamieszkania. Analiza przykładów architektury współczesnej, które w swojej formie lub materiale nawiązują do tradycji, kultury czy historii rodzimej jednostki.

Słowa kluczowe: człowiek, architektura, kształtowanie przestrzeni, tożsamość, dom

\section{Abstract}

The article deals with the tendencies in shaping the space around humanity, and connections between their identity and home traditions. The description of the meaning of family home in shaping the identity of the new living spaces. The analysis of the modern architecture examples which refer in their forms of materials to the traditions, culture or one's local history.

Keywords: human, architecture, identity, home 


\section{WSTĘP}

Tożsamość definiowana jest jako zespół cech, które stanowią o charakterze, specyfice miejsca i pozwalają na identyfikację jednostki lub całej społeczności. Pozwala ona utożsamiać się z elementami rzeczywistości społecznej. Stała się także silną potrzebą człowieka i niejako koniecznością w odnalezieniu się we współczesnym świecie. Poczucie własnej spójności, ciągłości bytu czy odrębności rodzi potrzebę identyfikacji, przynależności, a także bezpieczeństwa. Proces globalizacji, związany z nim wzrost ruchliwości współczesnych ludzi oraz intensywny proces indywidualizacji wytworzyły nowe warunki konstrukcji i rekonstrukcji tożsamości indywidualnych i zbiorowych (Dziekanowska, 2008: 1-2). Jednakże pomimo procesu globalizacji, która ma wpływ na identyfikację mieszkańców z miejscem zamieszkania i przebywania czy rodzin z ich tradycją i historią, zauważalne są powiązania z tożsamością i tradycją domu rodzinnego we współczesnych tendencjach w kształtowaniu przez człowieka otaczającej go przestrzeni. Temat owych powiązań i tendencji w kształtowaniu mikro-przestrzeni był przedmiotem naszych badań przeprowadzonych wśród respondentów z polskich uczelni wyższych. Badania miały na celu charakteryzację relacji pomiędzy elementami, które ukształtowały nasze postrzeganie przestrzeni a tendencjami w jej kształtowaniu na nowo w miejscach pozbawionych tożsamości domu rodzinnego.

\section{TOŻSAMOŚĆ DOMU RODZINNEGO}

Dom rodzinny i historia miejsca budują od podstaw tożsamość człowieka, są jej rdzeniem, dają poczucie przynależności do danej grupy społecznej czy kulturowej. Poczucie przynależności wiąże się również z poczuciem dobrostanu, które często definiuje architektura. Proces kształtowania i rozwoju tożsamości rozpoczyna się w najmłodszych latach życia człowieka i jest swoistą kontynuacją historii, uzupełnieniem zaistniałej już tożsamości rodzinnej. Jest niemal pewne, iż każda forma rozwoju młodej jednostki ludzkiej dokonuje się w rodzinie i podlega różnorodnym wpływom środowiska rodzinnego. Również proces kształtowania się tożsamości osobistej nie stanowi pod tym względem wyjątku. A zatem należy podkreślić, iż rozpatrywanie wpływu rodziny na rozwój i kształtowanie się tożsamości ma charakter wielowymiarowy czy wieloaspektowy (Rostowski, 2005: 13-15). Wielowymiarowość tego zagadnienia pozwala na rozpatrzenie go pod kątem architektury i wpływu tożsamości rodzimej na kształtowanie przestrzeni. Pytania o tożsamość powracają tym częściej, im bardziej staje się ona czymś zadanym, a nie danym z racji zajmowanego określonego miejsca w uporządkowanym i stabilnym świecie (Jawłowska, 2001: 51). W świecie, w którym żyjemy, każdy byt materialny ma swoją tożsamość nadaną przez człowieka. W swoich mieszkaniach i domach kształtujemy przestrzeń w taki sposób, by była ona dla nas zrozumiała i funkcjonalna, często nieświadomie posługując się językiem nawiązującym do tożsamości czy tradycji domu rodzinnego. Myśląc o domu rodzinnym 
jako o przestrzeni, która miała wpływ na naszą tożsamość, wspominamy pewną historię na bazie skojarzeń i emocji. Naturalnie dany nam świat przez „znaczących innych” jest nasycony silnymi związkami emocjonalnymi, które powodują, że dziecko bezrefleksyjnie przyjmuje ich zasady i wartości, podziela i dziedziczy kulturę, w której wzrasta. Ten świat i jego obraz ulegają reifikacji, stając się rzeczywistością, w której dziecko sytuuje siebie, czyli rozpoczyna świadome, odpowiedzialne kreowanie Ja, budowanie własnej tożsamości w postaci zbioru uświadamianych autocharakterystyk (Nikitorowicz, 2005: 61).

\section{KSZTAŁTOWANIE PRZESTRZENI A TOŻSAMOŚĆ LOKALNA}

Jednostka czerpie informacje o sobie i swojej grupie nie tylko z teraźniejszych wydarzeń, ale też z tego, co zdarzyło się kiedyś i co wyobrażamy sobie, że będzie potem. Tożsamość zanurzona jest w kontekst społeczno-kulturowy, nie tylko aktualnej rzeczywistości, ale też historii, zarówno własnego życia, jak i własnej rodziny, społeczności lokalnej, społeczeństwa, oraz ich przyszłości (Brzezińska, 2006: 49). Kiedy człowiek zostaje pozbawiony tożsamości wraz ze zmieniającą się rzeczywistością i przestrzenią rodzi się problem identyfikacji w nowym miejscu i społeczności. Zmiana środowiska i miejsca zamieszkania często powoduje uczucie wyobcowania i rodzi problem z odnalezieniem nowej tożsamości miejsca lub z przystosowaniem nowego miejsca do osobistych potrzeb. Wtedy właśnie zauważalny jest proces kształtowania nowej przestrzeni w taki sposób, by nadać jej nowe, ważne dla człowieka znaczenie. W procesie szukania swojej przestrzeni do życia łatwiejsze dla człowieka jest przystosowanie się do miejsc, w których pewne elementy składają się na formę przypominającą przestrzeń domu rodzinnego lub nawiązują do tożsamości lokalnej. Takimi elementami może być skala pomieszczenia lub mieszkania, klimat miejsca czy charakter architektury. Miejsca, które nawiązują do tożsamości lokalnej lub rodzimej, zapamiętanej przez nas, są lepiej odbierane i pomagają w kształtowaniu nowej przestrzeni do codziennego funkcjonowania.

\subsection{ELEMENTY TOŻSAMOŚCI PRZESTRZENI DOMU RODZINNEGO}

Powiązania sposobu aranżacji przestrzeni naszego codziennego funkcjonowania z tożsamością domu rodzinnego mogą przejawiać się w różnorodny sposób. W kreowaniu i aranżacji przestrzeni, w której żyjemy, często używamy elementów lub schematów, które pojawiały się w sposobie aranżacji naszych pierwotnie zamieszkałych domów. Potwierdzają to wyniki badań przeprowadzonych w formie swobodnego wywiadu, wśród kilkudziesięciu indywidualnych przypadków studentów różnorodnych wydziałów i uczelni na terenie Polski, między innymi Wydziału Architektury Politechniki Krakowskiej, Wydziału Prawa Uniwersytetu Śląskiego, Wydziału Prawa Uniwersytetu Jagiellońskiego czy też Wydziału Energetyki i Paliw Akademii Górniczo-Hutniczej w Krakowie. 
Początkowo respondenci zostali zapytani o podstawowe zagadnienia związane z tożsamością i domem rodzinnym. W odpowiedzi na pytanie o skojarzenia z domem rodzinnym pojawiły się hasła niezwykle ciekawe i różnorodne, takie jak: charakterystyczny dla domu kolor, pokój, w którym dorastali, ogród, materiały, atmosfera, rytuał parzenia czarnej herbaty o konkretnej godzinie, zakupy na lokalnym targu, obowiązki domowe czy duża wanna. Hasła te pokazują, w jak różnorodny sposób odbieramy otaczającą nas przestrzeń. Wspomnienie beztroski dzieciństwa tworzy obraz domu, którym chcemy się inspirować w tworzeniu swojego miejsca na ziemi. Respondenci zapytani o emocjonalny związek z domem rodzinnym opowiadali o jego różnych aspektach. Podkreślali znaczenie charakterystycznych miejsc w rodzinnej miejscowości, z którymi związana jest jakaś ważna dla nich historia, tęsknotę do „małej ojczyzny”, a także pozytywne emocje, jakie budzi w nich myśl o domu czy dzieciństwie.

W wypowiedziach studentów pojawił się też motyw oporu przed zmianami w domu, remontami, modyfikacjami pomieszczeń, które mogłyby zmienić to, jak dom wyglądał, kiedy byli dziećmi. Pozostawienie domu w formie architektonicznej, w jakiej funkcjonował od lat, budzi poczucie bezpieczeństwa i tego, że możemy czasem wrócić do tego, co było kiedyś. Sentyment związany z przedmiotami czy tradycją lokalną przejawia się w wielu wypowiedziach. Jednak zdecydowana większość respondentów podkreślała, że nie wyobraża sobie powrotu do domu rodzinnego w celu stworzenia tam swojej przestrzeni do życia na stałe. Pojawił się głos wśród studentów, który mówił, że dom rodzinny jest przesiąknięty historią dziadków czy rodziców i odczuwają oni niemożność stworzenia w nim swojej indywidualnej historii czy nowej formy. Spowodowane jest to również kwestią braku prywatności, braku swojego pokoju czy przestrzeni, w której można by było zamknąć drzwi na klucz i czuć się swobodnie. Jednakże w obliczu przestrzeni całego domu jeden własny kąt też może nam nie wystarczyć, by czuć się w pełni swobodnie. Jeden z respondentów w swojej wypowiedzi zaznaczył w opozycji do reszty, że przestrzeń, którą kreuje dla siebie, jest w opozycji do przestrzeni i atmosfery domu rodzinnego. Wiąże się to z próbą oderwania od dawnych przyzwyczajeń, stworzenia własnej odrębności i przestrzeni do życia, kreowania czegoś „,swojego”, wygodnego i prywatnego. Jednakże w każdym z badanych przypadków zauważalne jest parokrotnie odniesienie do tożsamości domu rodzinnego.

W małych miejscowościach czy na niewielkich osiedlach wiele domów i mieszkań ma cały czas „otwarte drzwi”, czyli każdy z domowników może przyjść do drugiego o każdej porze, a także nie ma wydzielonych stref prywatnych w domostwie. Domy są często odwiedzane i otworzone na spotkania z gośćmi. Dom rodzinny wypełniony ludźmi jest dla wielu osób pozytywnym aspektem, jednakże człowiek potrzebuje miejsca, w którym mógłby się skryć i urządzić je na własny, indywidualny sposób. Potrzeba prywatności i swojej własnej przestrzeni w domach rodzinnych jest akcentowana w wypowiedziach badanych osób. W dobie globalizacji wśród młodych ludzi rodzi się potrzeba silnej ekspresji, którą mogą wyrazić właśnie w aranżacji swojego miejsca do życia.

Kiedy zapytano respondentów o miejsce, w którym toczyło się życie domowników, jednogłośnie odpowiedzieli: kuchnia. Ciężko jest wyobrazić sobie dom rodzinny bez kuchni, w której 
stał duży stół z krzesłami - to tutaj spotykała się cała rodzina. Zazwyczaj kuchnia jako serce domu była najlepiej zorganizowanym pomieszczeniem. W domu rodzinnym wszystko miało swoje miejsce i porządek. W kuchni można było wyróżnić specjalne strefy, gdzie przechowywane były naczynia głębokie, płytkie, szklanki, kubki, sztućce czy chleb. Ergonomia i zorganizowanie przestrzeni do pracy wynikało z logiki, ale także z tradycji i przyzwyczajeń rodzinnych.

\section{JAK CZERPIEMY Z RODZINNYCH TRADYCJI, BUDUJĄC NOWA TOŻSAMOŚĆ?}

W nowo projektowanych mieszkaniach w centrach miast często nie ma miejsca na odpowiednią aranżację kuchni. Brak miejsca na szafki czy stół, przy którym można swobodnie zjeść posiłek, rodzi problem w organizacji przestrzeni w tym pomieszczeniu. Nasze przyzwyczajenia z domów rodzinnych przenosimy do nowych mieszkań, próbujemy wyznaczyć w pomieszczeniach strefy tak, by żyło się wygodnie. Czasem jednak jest to niemożliwe ze względu na brak odpowiedniego rozkładu pomieszczeń lub metrażu. Projektując swoją przestrzeń do życia, powielamy sprawdzone schematy układów z domu lub czerpiemy sposoby na rozmieszczenie przedmiotów w szafie. Organizacja miejsca w specyficzny dla dawnych przyzwyczajeń sposób jest charakterystyczna dla tendencji do kształtowania nowych przestrzeni.

We wnętrzach, jak i w samej architekturze kształtowanej przez człowieka pojawiają się charakterystyczne elementy kultury lokalnej czy regionalnej. W dobie globalizacji chętniej sięgamy po odnośniki do historii i tożsamości miejsca. Przykładem nawiązania do tożsamości regionu materiałem i formą architektoniczną może być projekt sopockiej pracowni architektonicznej Kruk Rasztawicki Architekci, a dokładniej dom A\&J autorstwa Marka Kruka i Marzeny Wytrykusz, który powstał w województwie pomorskim (il. 1).

W tradycyjnym domu przykrytym naczółkowym dachem usunięto wtórne dobudówki z lat 70., a otwory okienne, werandę i wejście do budynku odtworzono na podstawie archiwalnej dokumentacji. Poprzez wąski łącznik połączono bryłę istniejącego domu z nową - nowoczesną w formie, choć nawiązującą do zabytkowej tkanki. Architekci z pracowni Kruk Rasztawicki Architekci zdecydowali się na wprowadzenie dwukondygnacyjnej konstrukcji przykrytej tradycyjnym, dwuspadowym dachem o lekko przesuniętych względem siebie piętrach. Okna w dobudowanej części są na wskroś nowoczesne - wysokie i wąskie przeszklenia doświetlają mieszczące się wewnątrz pomieszczenia - salon na parterze i sypialnię na piętrze. Dominującym materiałem w zastanej tkance była ceramiczna dachówka w naturalnym kolorze, stosowana w tym okresie w większości domów rybackich na terenie Pomorza, którą pokryty był dach naczółkowy zabytkowej części. Nowa część została zrealizowana w nawiązaniu do naturalnego koloru ceramiki, w prostej formie, z wykorzystaniem współczesnych materiałów (il. 2). Jednolity kolor rozbudowywanej bryły wraz z minimalistycznym podejściem do detalu nadaje jej współczesny charakter, który nie dominuje nad historyczną częścią posiadającą zabytkowe detale (Kloc, 2020). 


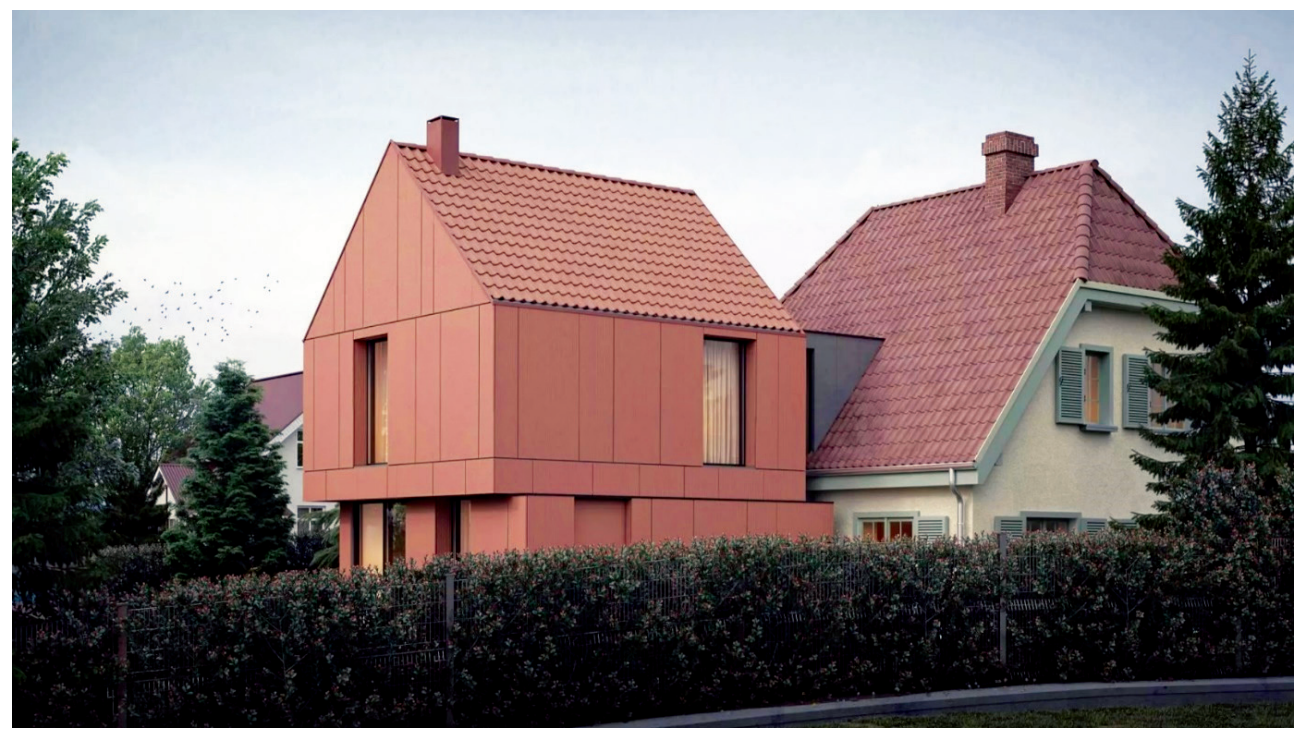

II. 1. Dom jednorodzinny A\&J, proj. Kruk Rasztawicki Architekci, województwo pomorskie. Widok na nowoczesną bryłę nawiązującą do tradycyjnej architektury poprzez kształt dachu oraz zastosowanie ceramicznej dachówki. Autor wizualizacji: Wydmy Studio (Kloc, 2020)

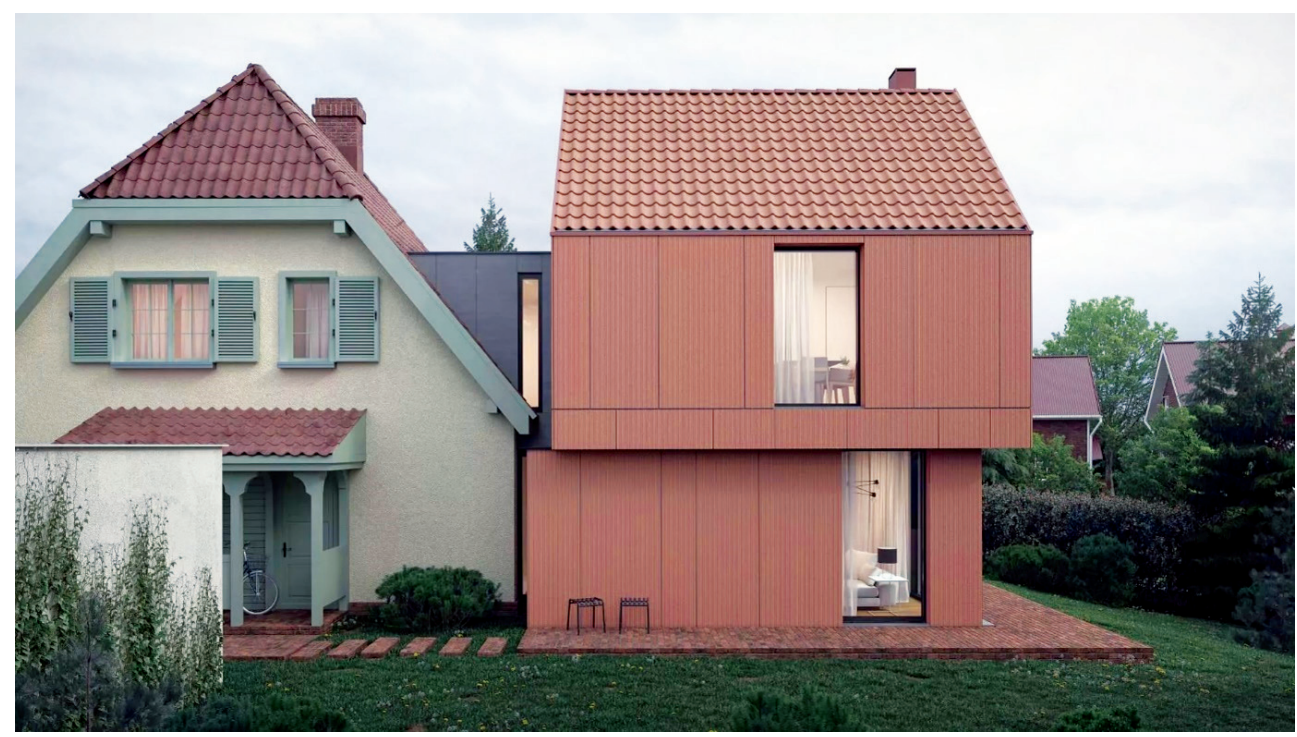

II. 2. Dom jednorodzinny A\&J, proj. Kruk Rasztawicki Architekci, województwo pomorskie. Widok pokazujący połączenie budynków wąskim łącznikiem. Autor wizualizacji: Wydmy Studio (Kloc, 2020) 
Drugim przykładem nawiązania do tożsamości regionu, tym razem z dziedziny architektury wnętrz, może być przestrzeń jednej z chorzowskich kamienic, która posiada specjalnie zaaranżowane miejsce, gdzie mieści się przestrzeń biura coworkingowego. Wnętrze łączy pierwotne elementy typowego śląskiego mieszkania z nowoczesnym dizajnem. Za ten mariaż tradycji i współczesności odpowiada biuro projektowe Ola Jachymiak Studio wraz z architektką Anną Drozdowską. DESKoteka, otwarta na początku ubiegłego roku, znajduje się przy ulicy Wolności w Chorzowie, a więc jednej z głównych arterii miasta. Jest to miejsce wpisujące się we współczesne trendy pracy - otwarte na potrzeby freelancerów i freelancerek czy firm bez stałej siedziby, a do tego z nowoczesnym dizajnem. Ola Jachymiak i Anna Drozdowska, organizując na nowo biurową przestrzeń o powierzchni około 75 metrów kwadratowych, zwróciły szczególną uwagę na istniejące we wnętrzu elementy typowego śląskiego mieszkania, a więc charakterystyczne drzwi, nadal funkcjonujące piece kaflowe, które zostały zmienione na elektryczne, a także specyficzną fakturę ścian. To właśnie te elementy stały się inspiracją dla projektu unikalnego biura z klimatem śląskiego domu, przełamanego industrialnymi elementami, związanymi z charakterem regionu (Oczkowska, 2021).
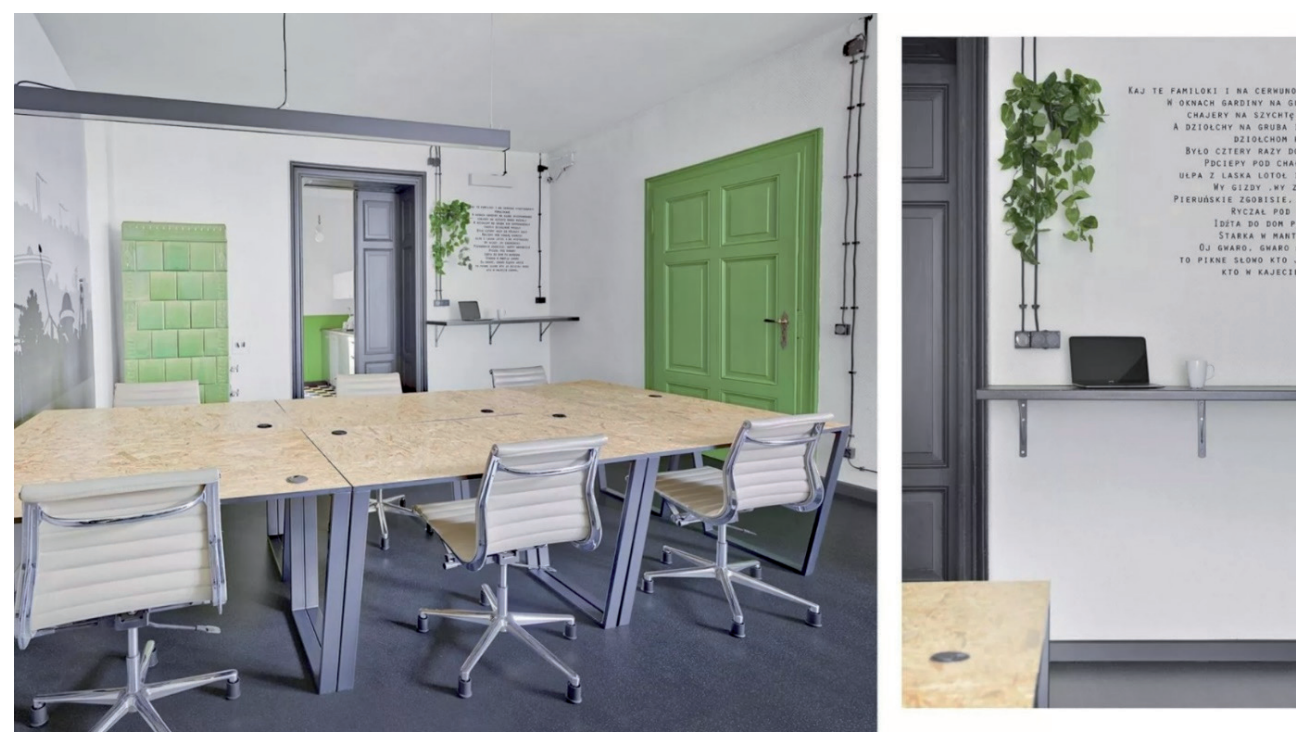

II. 3. DESKoteka, Ola Jachymiak Studio, Anna Drozdowska. Widok na zielony piec kaflowy i drzwi w przestrzeni biurowej DESKoteki w Chorzowie (Oczkowska, 2021)

Po rozwiązaniu kwestii układu przestrzeni Jachymiak i Drozdowska mogły zająć się swoim głównym celem projektowym - podkreśleniem zastanych we wnętrzu elementów oraz ich stuprocentowym wykorzystaniem. Inspiracją dla kolorystyki wnętrza stały się dwa piece 
kaflowe o barwie brązowej i zielonej, czyli charakterystycznej dla obszaru Śląska, co widać we współczesnej architekturze tego regionu. „Taki jest Śląsk: czerń pod ziemią, a zieleń na ziemi" - stwierdziły projektantki DESKoteki (Oczkowska, 2021). Wnętrze pieców zostało wyczyszczone, tak żeby mogły sprawnie działać, podobnie jak oczyszczone i pomalowane na czarno i zielono drzwi (il. 3). Ściany również zostały przemalowane, ale z zachowaniem pokrywającej je charakterystycznej tapety do malowania. Projektantki zdecydowały się na założenie industrialnej instalacji natynkowej, będącej dodatkowym, ciekawym detalem technicznym. W ten sposób został podkreślony charakter śląskiej kamienicy, uzupełniony o takie elementy jak nowa posadzka, stalowe nogi i meble czy blaty z OSB. Obydwie linie estetyczne, a więc śląskiego domu i przemysłowego miasta, tworzą tutaj spójną i atrakcyjną całość. Jeśli chodzi o tę pierwszą, to detalami typowo mieszczańskiego wnętrza są rośliny, firanki i piece. Z drugiej strony mamy natomiast elementy typowe dla architektury industrialnej, a więc stal, natynkowe instalacje elektryczne, proste środki i proste kolory oraz graficzną linię, reprezentowaną choćby przez podłogę w czarno-białą szachownicę (il. 4).

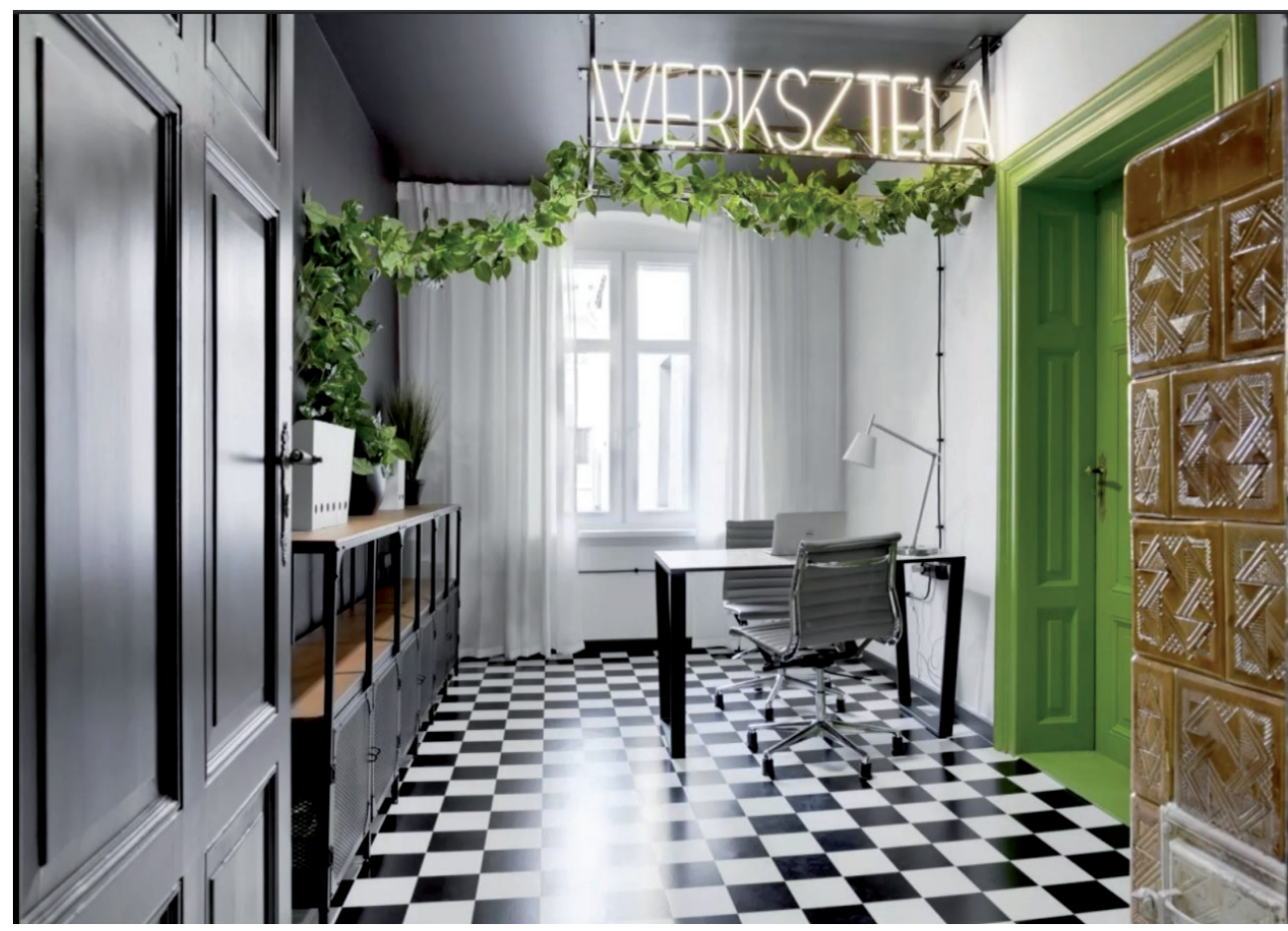

II. 4. DESKoteka, Ola Jachymiak Studio, Anna Drozdowska. Widok na zielone drzwi, piec kaflowy i podłogę w czarno-białą szachownicę w przestrzeni biurowej DESKoteki w Chorzowie (Oczkowska, 2021) 
Kolejnym śląskim akcentem, który wita gości DESKoteki już w recepcji, jest neon z napisem „Werksztela”, co w gwarze śląskiej oznacza „miejsce pracy/warsztat”. Dalej, kierując się do przestrzeni biurowej, odnajdziemy grafiki autorstwa Tak O. Natalia Fudała oraz świetne plakaty Ryszarda Kai, które tematycznie związane są ze Śląskiem. To bardzo istotne elementy, które wpływają nie tylko na estetykę wnętrza, ale również wspierają oraz propagują rodzimy dizajn na wysokim poziomie. Ponadto na jednej ze ścian odnajdziemy również tekst napisany gwarą śląską i zapisany prostym fontem, zaczynający się od słów: „Kaj te familoki...”. Jachymiak i Drozdowska zadbały o każdy detal, tworząc przestrzeń, łączącą to, co najlepsze, ale i trudne do zrealizowania: tradycję i teraźniejszość bez popadania w nostalgię (Oczkowska, 2021).

\section{TENDENCJE W KSZTAtTOWANIU PRZESTRZENI - TOŻSAMOŚĆ CZY GLOBALIZACJA?}

Proces globalizacji, związany z nim wzrost częstotliwości przemieszczania się ludzi oraz intensywny proces indywidualizacji wytworzyły nowe warunki konstrukcji i rekonstrukcji tożsamości indywidualnych i zbiorowych (Dziekanowska, 2008: 1-2). Tożsamość stała się nowym pryzmatem, przez który postrzegamy i wyjaśniamy współczesny świat. Myśl o posiadaniu tożsamości nie przychodzi ludziom do głowy tak długo, póki gdzieś przynależą, póki nie mają alternatywy. Człowiek „w ruchu” pozbawiony „naturalnego środowiska” nieustannie musi okazywać sobie i innym „kim jest” i „jaki jest” (Bauman 2007: 14-15). Wśród badanych respondentów większość stanowiły młode osoby, które ze względu na swoje ówczesne miejsce zamieszkania były zmuszone opuścić swoje domy rodzinne, rozpoczynając studia czy nową pracę. Migracje w celach edukacyjnych lub/i zarobkowych stawiają człowieka w sytuacji, w której pozbawiony wyżej wspomnianego „naturalnego środowiska” musi znaleźć swoje miejsce i przestrzeń do życia. Wyjazd do innego miasta, na przykład na studia, wiązał się z wyzbyciem się wszelakich przyzwyczajeń z domu rodzinnego, utratą komfortu czy bezpieczeństwa. Wolność od niewygodnych obowiązków domowych zestawiona zostaje w kontraście do ograniczenia przez stare przyzwyczajenia. Odczuwalna jest silna potrzeba ekspresji, przynależności, a także ulokowania się w nowym, obcym świecie. Wtedy też powstaje konieczność określenia siebie i swojego miejsca na ziemi, a także widoczne są tendencje w kreowaniu swojej przestrzeni w nowych mieszkaniach czy pokojach.

\section{PODSUMOWANIE I WNIOSKI}

Analizując wypowiedzi badanych respondentów, które odpowiadały na podstawowe pytania dotyczące zagadnień związanych z tożsamością i domem rodzinnym, emocjonalnych związków z nim czy skojarzeń, można potwierdzić słuszność stwierdzenia, iż dom rodzinny ma duże znaczenie w kształtowaniu tożsamości nowego miejsca zamieszkania. W aranżacjach wnętrz coraz częściej zauważalne jest przemycanie elementów architektury z tradycji 
czy kultury lokalnej. Takimi elementami mogą być na przykład kafle w tradycyjny wzór, cegła, drewniane elementy, rękodzieło, porcelana z dawnych lat, nowoczesne lastryko czy powrót do PRL-u i odnawianie starych szafek i foteli, by nadać im nowe życie w nowym domu. Przemycając do naszego nowego życia elementy architektury, które towarzyszyły nam w dzieciństwie, w nowych, obcych nam pomieszczeniach czujemy się bardziej „swojsko”. Motywy regionalne czy lokalne pojawiają się również coraz częściej w aranżacjach mieszkań nowoczesnych jako kontrast czy akcent. Znaczenie tożsamości lokalnej w kreowaniu swojego miejsca do codziennego funkcjonowania objawia się zatem wielowymiarowo. Młode osoby, które szukają swojego miejsca i mają silną potrzebę bezpieczeństwa, ekspresji i przynależności, poszukują swojej tożsamości w historii rodzinnej czy lokalnej/regionalnej. Wykorzystanie elementów tradycyjnych dla regionu czy kultury rodzimej jest również przejawem szacunku dla miejsca i jego architektury. Tożsamość w skali mikro związana jest ściśle z człowiekiem i jego najbliższą przestrzenią, którą często definiują elementy nawiązujące do znanych nam form architektonicznych i układów funkcjonalnych. Stosowanie odniesień do tradycji czy znanej nam formy architektonicznej nie wyklucza możliwości ewolucji odbioru i odczuwania tożsamości i jest otwartym na interpretację zagadnieniem.

\section{BIBLIOGRAFIA}

Bauman, Z. (2001). Wokół problemów tożsamości. W: A. Jawłowska (red.), Tożsamość -jaka była, jest i po co?. Warszawa: Instytut Stosowanych Nauk Społecznych i Wydawnictwo LTW.

Bauman, Z. (2007). Tożsamość. Rozmowy z Benedetto Vecchim. Gdańsk: Gdańskie Wydawnictwo Psychologiczne.

Brzezińska, A. (2006). Dzieciństwo i dorastanie: korzenie tożsamości osobistej i społecznej. W: A.W. Brzezińska, A. Hulewska, J. Słomska (red.), Edukacja regionalna. Warszawa.

Dziekanowska, M. (2008). Tożsamość społeczna a globalizacja. Zeszyty Naukowe Uniwersytetu Szczecińskiego, 517, 1-2.

Kloc, A. (2020). Gdy tradycja łączy się z nowoczesnościq. Dom jednorodzinny od Kruk Rasztawicki Architekci. Pobrane z: https://www.architekturaibiznes.pl/nowoczesny-i-tradycyjny-dom-jednorodzinny,4926.html?fbclid=IwAR1PbDWi8qVb0zx9ka8T8EmjGPCY93BaUSZc nQxMt3jS3_Ty-eP44qKKz1A (dostęp: 30.06.2021).

Nikitorowicz, J. (2005). Kreowanie tożsamości dziecka. Wyzwania edukacji międzykulturowej. Gdańsk.

Oczkowska, K. (2021). DESKoteka czyli coworking po ślqqsku. Pobrane z: https://www.architekturaibiznes.pl/deskoteka-czyli-coworking-po-slasku,5357.html?fbclid=lwAR0cvG0aDK8e 25iBNpYVIH4X5Cok5IhcR1--L78PLplpGpDo8nnMiTI2Z5U (dostęp: 30.06.2021).

Rostowski, J. (2005). Rodzinne uwarunkowania kształtowania się tożsamości osobowej człowieka. Psychologia Rozwojowa, 2(10), 13-15. 